\title{
Ralstonia respiraculi sp. nov., isolated from the respiratory tract of cystic fibrosis patients
}

\author{
Tom Coenye, ${ }^{1}$ Peter Vandamme ${ }^{2}$ and John J. LiPuma ${ }^{1}$ \\ ${ }^{1}$ Department of Pediatrics and Communicable Diseases, University of Michigan, 1150 W. Med. \\ Ctr Dr, MSRB III, Rm 8323, Ann Arbor, Ml 48109-0646, USA
${ }^{2}$ Laboratorium voor Microbiologie, Universiteit Gent, K. L. Ledeganckstraat 35, B-9000 Gent, Belgium

Tom Coenye

tom.coenye@ugent.be

\begin{abstract}
Five isolates recovered from the respiratory tract of cystic fibrosis patients were included in a polyphasic taxonomic study that employed 16S rDNA sequence analysis, cellular protein and fatty acid analysis and biochemical characterization. Four isolates were classified as a novel Ralstonia species, for which the name Ralstonia respiraculi sp. nov. is proposed; the other isolate was phylogenetically closely related to $R$. respiraculi, but is likely to represent another novel Ralstonia species. The type strain of $R$. respiraculi is AU3313 ${ }^{\top}\left(=\mathrm{LMG} 21510^{\top}=\right.$ CCUG $\left.46809^{\top}\right)$.
\end{abstract}

Individuals with the inherited disease cystic fibrosis (CF) are susceptible to a plethora of potentially life-threatening respiratory infections. It has been suggested that this is due to the fact that the respiratory system of a CF patient is an ecological niche that is suitable for growth of a wide variety of bacteria (Coenye et al., 2002a). While Pseudomonas aeruginosa and Burkholderia cepacia complex organisms are typical CF pathogens (Gilligan, 1991), Burkholderia gladioli, Stenotrophomonas maltophilia, Achromobacter xylosoxidans, members of the Enterobacteriaceae and various Ralstonia species can also be isolated from respiratory secretions of CF patients (Burns et al., 1998; Coenye et al., 2002a, b).

At the time of writing, the genus Ralstonia contains twelve species with validly published names: Ralstonia pickettii (the type species), Ralstonia solanacearum, Ralstonia eutropha (Yabuuchi et al., 1995), Ralstonia basilensis (Steinle et al., 1998), Ralstonia gilardii (Coenye et al., 1999), Ralstonia paucula (Vandamme et al., 1999), Ralstonia oxalatica (Sahin et al., 2000), Ralstonia mannitolilytica (De Baere et al., 2001), Ralstonia campinensis, Ralstonia metallidurans (Goris et al., 2001), Ralstonia taiwanensis (Chen et al., 2001) and Ralstonia insidiosa (Coenye et al., 2003). R. pickettii, $R$. mannitolilytica, $R$. gilardii, R. taiwanensis and R. insidiosa

Published online ahead of print on 24 January 2003 as DOI 10.1099/ ijs.0.02440-0.

Abbreviation: $\mathrm{CF}$, cystic fibrosis.

The GenBank/EMBL/DDBJ accession numbers for the 16S rRNA gene sequences of strains AU3313 ${ }^{\top}, A U 3801$, AU0626, AU1618 and AU3369 are AF500583, AF500584, AF500585, AF500586 and AF500587, respectively.

Protein profiles of the $R$. respiraculi strains, strain AU3369 and reference strains of other Ralstonia species are available as supplementary material in IJSEM Online. have been isolated from various clinical samples, including respiratory secretions of CF patients (Burns et al., 1998; Chen et al., 2001; Coenye et al., 2002a, b). In addition, a number of unidentified Ralstonia sp. isolates have been recovered from CF patients (Coenye et al., 2002a, b). Here, we report on the polyphasic taxonomic study of five such Ralstonia sp. isolates that were recovered from the respiratory tract of CF patients.

The five strains studied (AU0626, AU1618, AU3313 ${ }^{\mathrm{T}}$, AU3801 and AU3369) were isolated from different CF patients who were receiving care in five CF treatment centres in three different US states. Dates of isolation were between December 1997 and January 2002. Reference strains of other Ralstonia species have been described previously (Coenye et al., 1999, 2003; Vandamme et al., 1999; Chen et al., 2001; De Baere et al., 2001; Goris et al., 2001). Strains were grown aerobically on Mueller-Hinton broth (Becton Dickinson) supplemented with $1.8 \%(\mathrm{w} / \mathrm{v})$ agar and incubated overnight at $32{ }^{\circ} \mathrm{C}$, unless otherwise mentioned. Preparation of DNA, amplification of the $16 \mathrm{~S}$ rRNA gene by PCR and 16S rDNA sequencing was performed as described previously (Coenye et al., 2002a). Preparation of whole-cell proteins and SDS-PAGE were performed as described by Pot et al. (1994). Strains were grown for $48 \mathrm{~h}$ on Trypticase Soy Agar (BBL) and incubated at $37^{\circ} \mathrm{C}$. Densitometric analysis, normalization and interpolation of protein profiles and numerical analysis were performed by using GelCompar 4.2 software (Applied Maths). Cellular fatty acid analysis and conventional biochemical testing were performed as described by Coenye et al. (1999 and 2003, respectively). RapID NF Plus (Remel) and API 20NE (bioMérieux) commercial identification systems were used according to the recommendations of the manufacturers. Species-specific 16S rDNA-based PCR assays for the identification of Burkholderia-Ralstonia-Pandoraea sp., 


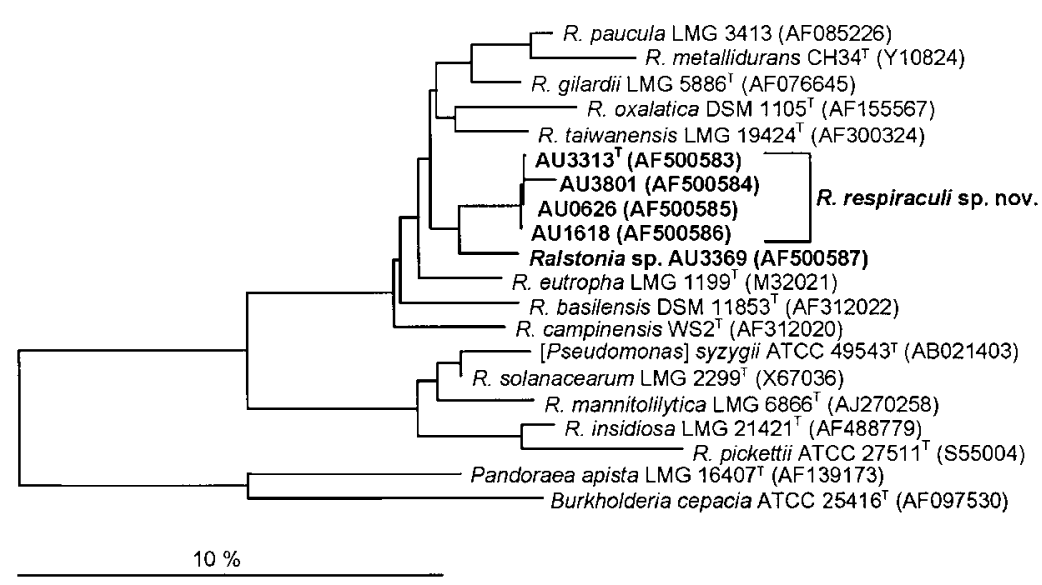

Fig. 1. Phylogenetic tree (based on $16 \mathrm{~S}$ rDNA sequences) showing the position of $R$. respiraculi and Ralstonia sp. AU3369 within the genus Ra/stonia. Bar, $10 \%$ sequence dissimilarity.
R. pickettii, R. mannitolilytica, R. insidiosa and A. xylosoxidans were performed as described previously (LiPuma et al., 1999; Coenye et al., 2002b, 2003; Liu et al., 2002).

The 16S rRNA genes of strains AU0626, AU1618, AU3313 ${ }^{\mathrm{T}}$ and AU3801 showed high sequence similarity to each other (mean similarity value, $98 \cdot 8 \%$ ) and to the $16 \mathrm{~S}$ rRNA gene of strain AU3369 (mean similarity value, 98.3\%). Comparison of these sequences with $16 \mathrm{~S}$ rRNA gene sequences available in GenBank indicated that they belonged to the genus Ralstonia (Fig. 1). Sequence similarity values to reference strains of $R$. eutropha, $R$. taiwanensis, $R$. paucula and $R$. campinensis were between $97 \cdot 2$ and $96 \cdot 1 \%$, whilst similarity to the $16 \mathrm{~S}$ rRNA genes of other Ralstonia species was $<95.4 \%$ (Fig. 1). Visual comparison of the whole-cell protein profiles (see supplementary material in IJSEM Online) indicated that strains AU0626, AU1618, AU3313 ${ }^{\mathrm{T}}$ and AU3801 were characterized by highly similar protein patterns, whereas strain AU3369 and reference strains of other Ralstonia species showed clearly different protein patterns.

The cellular fatty acid compositions of strains AU0626, AU1618, AU3313 ${ }^{\mathrm{T}}$ and AU3801 were very similar and the following fatty acids were present in all four strains $\left(\right.$ mean \pm SD): $\mathrm{C}_{14: 0}(4 \cdot 49 \pm 0 \cdot 51 \%), \mathrm{C}_{14: 0} 3-\mathrm{OH}(8 \cdot 56 \pm$ $0 \cdot 75 \%), \mathrm{C}_{16: 1} \omega 7 c(31 \cdot 23 \pm 3 \cdot 85 \%), \mathrm{C}_{16: 0}(23 \cdot 56 \pm 3 \cdot 61 \%)$, $\mathrm{C}_{17: 0}$ cyclo $(7 \cdot 42 \pm 3 \cdot 19 \%), \mathrm{C}_{16: 0} 2-\mathrm{OH}(1 \cdot 21 \pm 0 \cdot 24 \%)$, $\mathrm{C}_{18: 1} \omega 7 c(20 \cdot 38 \pm 5 \cdot 26 \%)$ and $\mathrm{C}_{18: 1} 2-\mathrm{OH}(1 \cdot 85 \pm 0 \cdot 53 \%)$. Trace amounts $(<1 \cdot 0 \%)$ of $\mathrm{C}_{14: 0} 2-\mathrm{OH}$ and $\mathrm{C}_{18: 0}$ were also present. The fatty acid composition of strain AU3369 was very similar to those of strains AU0626, AU1618, AU3313 ${ }^{\mathrm{T}}$ and AU3801 (data not shown).

All strains grew at 28,32 and $37^{\circ} \mathrm{C}$. Growth on B. cepaciaselective agar (BCSA) was not observed. All strains showed oxidase, catalase, pyrrolidonyl aminopeptidase and $\gamma$-Lglutamyl aminopeptidase activities and assimilated gluconate, caprate, adipate and malate. Lysine decarboxylase, arginine dihydrolase, urease, lipase, $\beta$-glucosidase, gelatinase, $\beta$-galactosidase, tryptophan aminopeptidase, $N$ benzylarginine aminopeptidase, proline aminopeptidase, tryptophan aminopeptidase and $N$-acetylglucosaminidase activities were not observed. None of the strains assimilated glucose, arabinose, mannose, mannitol, $\mathrm{N}$-acetylglucosamine, maltose, citrate or phenylacetate. Indole production and production of acid from glucose, sucrose or lactose were not observed. Nitrate reduction and the presence of lipase, phosphatase and $\alpha$-glucosidase activity were straindependent characteristics. By using the API 20NE system, strains were either identified with a low score as Alcaligenes faecalis, Comamonas testosteroni, Pseudomonas alcaligenes or Comamonas acidovorans (for strains that reduced nitrate, profile 1000474), or were identified with a low score as R. paucula, Alcaligenes faecalis, Comamonas testosteroni or Pseudomonas alcaligenes (for strains that did not reduce nitrate, profile 0000474). No adequate identification was obtained by using the RapID NF Plus system. None of the five strains gave a positive result with the PCR assays developed for the identification of $R$. pickettii, $R$. mannitolilytica, $R$. insidiosa or A. xylosoxidans, but all gave positive results in the Burkholderia-RalstoniaPandoraea PCR test.

We performed a polyphasic taxonomic study to determine the taxonomic position of five strains isolated from the respiratory tract of CF patients in the USA. 16S rDNA sequence analysis indicated that these strains were closely related to each other and belonged to the genus Ralstonia. Their closest phylogenetic neighbours were R. eutropha and $R$. taiwanensis, but mean sequence similarity to the type strains of these species was $<97 \cdot 2 \%$. Biochemical characteristics and cellular fatty acid compositions of these isolates were very similar, but the one-dimensional protein profile of isolate AU3369 was clearly different from those of the other four isolates. The profiles of the five strains investigated were clearly different from those of all other Ralstonia species. Our data clearly indicate that isolates AU0626, AU1618, AU3313 ${ }^{\mathrm{T}}$ and AU3801 belong to a single novel Ralstonia species, for which we propose the name Ralstonia respiraculi sp. nov. Based on $16 \mathrm{~S}$ rDNA sequence analysis and SDS-PAGE of whole-cell proteins, isolate AU3369 probably constitutes a distinct Ralstonia species. However, we do not propose a formal name for this taxon, 
Table 1. Characteristics that are useful for the differentiation of $R$. respiraculi and strain AU3369 from other Ralstonia species

Species: 1, R. respiraculi; 2, Ralstonia sp. AU3369; 3, R. eutropha; 4, R. campinensis; 5, R. basilensis; 6, R. metallidurans; 7, R. taiwanensis; 8, $R$. paucula; 9, R. gilardii; 10, R. pickettii; 11, R. mannitolilytica; $12, R$. solanacearum; 13, R. insidiosa; 14, R. oxalatica. Data for $R$. oxalatica are taken from Gillis et al. (1995); data for $R$. insidiosa are taken from Coenye et al. (2003); data for all other Ralstonia species are taken from Coenye et al. (1999), Vandamme et al. (1999), Chen et al. (2001), De Baere et al. (2001) and Goris et al. (2001). Reactions are scored as:,$+>90 \%$ of strains investigated react positively;,$-<10 \%$ of strains investigated react positively; v, 10-90\% of strains investigated react positively.

\begin{tabular}{|llllllllllllllll}
\hline Characteristic & $\mathbf{1}$ & $\mathbf{2}$ & $\mathbf{3}$ & $\mathbf{4}$ & $\mathbf{5}$ & $\mathbf{6}$ & $\mathbf{7}$ & $\mathbf{8}$ & $\mathbf{9}$ & $\mathbf{1 0}$ & $\mathbf{1 1}$ & $\mathbf{1 2}$ & $\mathbf{1 3}$ & $\mathbf{1 4}$ \\
\hline Urease activity & - & - & - & + & - & - & + & + & - & + & + & - & $\mathrm{V}$ & $\mathrm{V}$ \\
Assimilation of: & & & & & & & & & & & & \\
$\quad$ N-Acetylglucosamine & - & - & + & - & - & - & - & - & - & + & + & - & - & $\mathrm{V}$ \\
Citrate & - & - & + & - & + & + & + & + & - & + & + & + & + & + \\
Phenylacetate & - & - & + & + & + & + & + & + & $\mathrm{V}$ & + & - & - & + \\
\end{tabular}

pending the recovery of similar isolates and availability of biochemical tests to differentiate it from $R$. respiraculi.

Biochemical characteristics that are useful for the differentiation of $R$. respiraculi and Ralstonia sp. AU3369 from other Ralstonia species are given in Table 1. Differentiation from A. xylosoxidans is possible by lack of acidification of glucose (von Graevenitz, 1995). In contrast to B. cepacia complex species (Henry et al., 2001), R. respiraculi and strain AU3369 do not show $\beta$-galactosidase or lysine decarboxylase activities and do not grow on BCSA. In addition to these biochemical characteristics, differentiation from other Ralstonia species that may be encountered in CF specimens ( $R$. pickettii, $R$. mannitolilytica and $R$. insidiosa) and from A. xylosoxidans is possible by using the PCR-based assays that were described previously for the identification of these organisms (Coenye et al., 2002b, 2003; Liu et al., 2002).

\section{Description of Ralstonia respiraculi sp. nov.}

Ralstonia respiraculi (re.spi.ra'cu.li. L. n. respiraculum breathing, respiration; L. gen. n. respiraculi of breathing, of the respiratory system).

Cells are Gram-negative, non-fermentative, non-sporulating, motile rods. Growth is observed at 28,32 and $37^{\circ} \mathrm{C}$. No growth is observed on BCSA. Catalase and oxidase activities are present. No lysine decarboxylase, urease, $\beta$-galactosidase or lipase activities are present. No indole production occurs. No production of acid from glucose, sucrose or lactose occurs in oxidation-fermentation medium. Gluconate, caprate, adipate and malate are assimilated but glucose, arabinose, mannose, mannitol, $\mathrm{N}$-acetylglucosamine, maltose, citrate and phenylacetate are not. Additional characteristics are given above. The following fatty acids are present: $\mathrm{C}_{14: 0}, \mathrm{C}_{14: 0} 3-\mathrm{OH}, \mathrm{C}_{16: 1} \omega 7 c, \mathrm{C}_{16: 0}, \mathrm{C}_{17: 0}$ cyclo, $\mathrm{C}_{16: 0} 2-\mathrm{OH}, \mathrm{C}_{18: 1} \omega 07 c$ and $\mathrm{C}_{18: 1}$ 2-OH. Characteristics that differentiate $R$. respiraculi from other Ralstonia species are summarized in Table 1.

The type strain, AU3313 ${ }^{\mathrm{T}}$, was isolated from the sputum of a CF patient in the USA in 2001. Phenotypic characteristics are the same as described above for the species. In addition, the type strain shows phosphatase and $\alpha$-glucosidase activities but no lipase activity, and reduces nitrate. $R$. respiraculi strains AU3313 ${ }^{\mathrm{T}}$ and AU1618 have been deposited in the BCCM/LMG (Laboratorium voor Microbiologie Gent, Belgium) and CCUG (University of Göteborg, Department of Clinical Bacteriology, Göteborg, Sweden) culture collections as LMG $21510^{\mathrm{T}}\left(=\right.$ CCUG $\left.46809^{\mathrm{T}}\right)$ and LMG 21509 (=CCUG 46808), respectively.

\section{Acknowledgements}

This work was supported by a grant from the Cystic Fibrosis Foundation (United States) (to J. J. L.). T.C. is supported by the Caroll Haas Research Fund in Cystic Fibrosis. P. V. is indebted to the Fund for Scientific Research - Flanders for financial support.

\section{References}

Burns, J. L., Emerson, J., Stapp, J. R., Yim, D. L., Krzewinski, J., Louden, L., Ramsey, B. W. \& Clausen, C. R. (1998). Microbiology of sputum from patients at cystic fibrosis centers in the United States. Clin Infect Dis 27, 158-163.

Chen, W.-M., Laevens, S., Lee, T.-M., Coenye, T., De Vos, P., Mergeay, M. \& Vandamme, P. (2001). Ralstonia taiwanensis sp. nov., isolated from root nodules of Mimosa species and sputum of a cystic fibrosis patient. Int J Syst Evol Microbiol 51, 1729-1735.

Coenye, T., Falsen, E., Vancanneyt, M., Hoste, B., Govan, J. R. W., Kersters, K. \& Vandamme, P. (1999). Classification of Alcaligenes faecalis-like isolates from the environment and human clinical samples as Ralstonia gilardii sp. nov. Int J Syst Bacteriol 49, 405-413. Coenye, T., Goris, J., Spilker, T., Vandamme, P. \& LiPuma, J. J. (2002a). Characterization of unusual bacteria isolated from respiratory secretions of cystic fibrosis patients and description of Inquilinus limosus gen. nov., sp. nov. J Clin Microbiol 40, 2062-2069. Coenye, T., Vandamme, P. \& LiPuma, J. J. (2002b). Infection by Ralstonia species in cystic fibrosis patients: identification of $R$. pickettii and $R$. mannitolilytica by polymerase chain reaction. Emerg Infect Dis 8, 692-696.

Coenye, T., Goris, J., De Vos, P., Vandamme, P. \& LiPuma, J. J. (2003). Classification of Ralstonia pickettii-like isolates from the environment and clinical samples as Ralstonia insidiosa sp. nov. Int J Syst Evol Microbiol 53, 1075-1080. 
De Baere, T., Steyaert, S., Wauters, G., De Vos, P., Goris, J., Coenye, T., Suyama, T., Verschraegen, G. \& Vaneechoutte, M. (2001). Classification of Ralstonia pickettii biovar 3/'thomasii' strains (Pickett 1994) and of new isolates related to nosocomial recurrent meningitis as Ralstonia mannitolytica sp. nov. Int J Syst Evol Microbiol 51, 547-558.

Gilligan, P. H. (1991). Microbiology of airway disease in patients with cystic fibrosis. Clin Microbiol Rev 4, 35-51.

Gillis, M., Van Van, T., Bardin, R. \& 7 other authors (1995). Polyphasic taxonomy in the genus Burkholderia leading to an emended description of the genus and proposition of Burkholderia vietnamiensis sp. nov. for $\mathrm{N}_{2}$-fixing isolates from rice in Vietnam. Int J Syst Bacteriol 45, 274-289.

Goris, J., De Vos, P., Coenye, T. \& 7 other authors (2001). Classification of metal-resistant bacteria from industrial biotopes as Ralstonia campinensis sp. nov., Ralstonia metallidurans sp. nov. and Ralstonia basilensis Steinle et al. 1998 emend. Int J Syst Evol Microbiol 51, 1773-1782.

Henry, D. A., Mahenthiralingam, E., Vandamme, P., Coenye, T. \& Speert, D. P. (2001). Phenotypic methods for determining genomovar status of the Burkholderia cepacia complex. J Clin Microbiol 39, 1073-1078.

LiPuma, J. J., Dulaney, B. J., McMenamin, J. D., Whitby, P. W., Stull, T. L., Coenye, T. \& Vandamme, P. (1999). Development of rRNA-based PCR assays for identification of Burkholderia cepacia complex isolates recovered from cystic fibrosis patients. J Clin Microbiol 37, 3167-3170.

Liu, L., Coenye, T., Burns, J. L., Whitby, P. W., Stull, T. L. \& LiPuma, J. J. (2002). Ribosomal DNA-directed PCR for identification of
Achromobacter (Alcaligenes) xylosoxidans recovered from sputum samples from cystic fibrosis patients. J Clin Microbiol 40, 1210-1213.

Pot, B., Vandamme, P. \& Kersters, K. (1994). Analysis of electrophoretic whole-organism protein fingerprints. In Chemical Methods in Prokaryotic Systematics, pp. 493-521. Edited by M. Goodfellow \& A. G. J. O'Donnell. Chichester, UK: Wiley.

Sahin, N., Isik, K., Tamer, A. U. \& Goodfellow, M. (2000). Taxonomic position of "Pseudomonas oxalaticus" strain Ox14 $4^{\mathrm{T}}\left(\mathrm{DSM} 1105^{\mathrm{T}}\right.$ ) (Khambata and Bhat, 1953) and its description in the genus Ralstonia as Ralstonia oxalatica comb. nov. Syst Appl Microbiol 23, 206-209.

Steinle, P., Stucki, G., Stettler, R. \& Hanselmann, K. W. (1998). Aerobic mineralization of 2,6-dichlorophenol by Ralstonia sp. strain RK1. Appl Environ Microbiol 64, 2566-2571.

Vandamme, P., Goris, J., Coenye, T., Hoste, B., Janssens, D., Kersters, K., De Vos, P. \& Falsen, E. (1999). Assignment of Centers for Disease Control group IVc-2 to the genus Ralstonia as Ralstonia paucula sp. nov. Int J Syst Bacteriol 49, 663-669.

von Graevenitz, A. (1995). Acinetobacter, Alcaligenes, Moraxella, and other nonfermentative Gram-negative bacteria. In Manual of Clinical Microbiology, 6th edn, pp. 520-532. Edited by P. R. Murray, E. J. Baron, M. A. Pfaller, F. C. Tenover \& R. H. Yolken. Washington, DC: ASM Press.

Yabuuchi, E., Kosako, Y., Yano, I., Hotta, H. \& Nishiuchi, Y. (1995). Transfer of two Burkholderia and an Alcaligenes species to Ralstonia gen. nov.: proposal of Ralstonia pickettii (Ralston, Palleroni and Doudoroff 1973) comb. nov., Ralstonia solanacearum (Smith 1896) comb. nov. and Ralstonia eutropha (Davis 1969) comb. nov. Microbiol Immunol 39, 897-904. 